\title{
TINGKAT PERTUMBUHAN DAN PRODUKSI TANAMAN KEDELAI PADA BERBAGAI JARAK TANAM DAN KONSENTRASI GIBERELIN
}

\author{
THE GROWTH AND PRODUCTION LEVEL OF SOYBEAN (Glycine max L. \\ MERRIL) ON VARIOUS SPACING AND GIBBERELLINS CONSENTRATION
}

\author{
Muhammad Nazaruddin, and Irmayanti \\ Agroecotechnology Departement, Agriculture Faculty, Universitas Malikussaleh, North Aceh, \\ Indonesia 24355 \\ Corresponding Author: mnazaruddin@unimal.ac.id
}

\begin{abstract}
ABSTRAK
Penelitian ini bertujuan untuk mengetahui pengaruh jarak tanam dan konsentrasi giberelin (GA3) terhadap pertumbuhan dan hasil tanaman kedelai. Desain yang digunakan adalah rancangan acak kelompok faktorial dengan 2 faktor dan 3 ulangan. Faktor-faktor yang diteliti adalah jarak tanam yang terdiri dari 3 tingkatan, yaitu: J1 dengan jarak $40 \mathrm{~cm} \times 20 \mathrm{~cm}$, $\mathrm{J} 2$ dengan jarak $40 \mathrm{~cm} \times 15 \mathrm{~cm}, \mathrm{~J} 3$ dengan jarak $30 \mathrm{~cm} \times 30 \mathrm{~cm}$, dan faktor konsentrasi giberelin yang terdiri dari 4 kadar, yaitu: G0 tanpa aplikasi giberelin, konsentrasi G1 75 ppm, konsentrasi G2 95 ppm, konsentrasi G3 115 ppm. Perlakuan jarak tanam secara signifikan mempengaruhi jumlah cabang produktif dan berat kering100 biji. Perlakuan terbaik ditemukan pada jarak $30 \mathrm{~cm}$ x $30 \mathrm{~cm}$ (J3). Konsentrasi giberelin memiliki efek yang sangat signifikan terhadap tinggi tanaman pada 45 dan 60 hari setelah tanam dan berat kering 100 biji. Perlakuan terbaik ditemukan pada konsentrasi 95 ppm.
\end{abstract}

Kata kunci: kedelai, jarak tanam, giberelin

\begin{abstract}
This study aims to determine the effect of spacing and concentration of gibberellins (GA3) on the growth and yield of soybean plants. The design used was a factorial randomized block design with 2 factors and 3 replications. The factors studied are spacing consisting of 3 levels, namely: $J_{1}$ with spacing of $40 \mathrm{~cm} \times 20 \mathrm{~cm}, J_{2}$ with spacing of $40 \mathrm{~cm} \times 15 \mathrm{~cm}, J_{3}$ with spacing of $30 \mathrm{~cm} \times 30 \mathrm{~cm}$, and giberelin concentration factor which consists of 4 levels, namely: $G_{0}$ without giberelin application, $G_{1}$ concentration of $75 \mathrm{ppm}, \mathrm{G}_{2}$ concentration of 95 $\mathrm{ppm}, \mathrm{G}_{3}$ concentration of $115 \mathrm{ppm}$. Spacing treatment significantly affected the number of productive branches and dry weight of 100 seeds. The best treatment was found at a spacing of $30 \mathrm{~cm} \times 30 \mathrm{~cm}\left(\mathrm{~J}_{3}\right)$. The concentration of gibberellins has a very significant effect on plant height at 45 and 60 days after planting and 100 seeds dry weight. The best treatment was found at a concentration of $95 \mathrm{ppm}$.
\end{abstract}

Keywords: soybean, planting distance, gibberellins

\section{PENDAHULUAN}

Kedelai merupakan salah satu sumber protein penting dan murah yang diproduksi di seluruh dunia (Fried et al., 2018). Tanaman kedelai (Glycine max L. Merrill) telah lama diusahakan di Indonesia, dan menjadi salah satu tanaman pangan yang penting untuk diperhatikan. Permintaan kedelai semakin meningkat dari tahun ke tahun seiring dengan bertambahnya penduduk dan meningkatkan kesadaran 
masyarakat terhadap makanan berprotein nabati. Kedelai dapat digunakan untuk memenuhi kebutuhan gizi masyarakat sebab mengandung protein yang tinggi. Adapun kandungan tanaman kedelai diantaranya protein nabati, karbohidrat dan lemak. Biji kedelai juga mengandung fosfor, besi, kalsium, vitamin B dengan komposisi asam amino lengkap (Fauzi dan Puspitawati, 2018).

Beberapa tahun terakhir ini produksi kedelai nasional terus mengalami fluktuasi. Produksi kedelai pada tahun 2006 mengalami penurunan menjadi 747.611 ton, bahkan sempat mengalami penurunan drastis menjadi 592.534 ton pada tahun 2007. Produksi kedelai mulai mengalami peningkatan kembali menjadi 775.710 ton pada tahun 2008 dan 974.512 ton pada tahun 2009. Sedangkan pada kurun waktu berikutnya 2013, 2014 dan 2015, produksi kedelai terus mengalami peningkatan yaitu 779.992 ton, 954.997 ton, dan 963.183 ton (BPS, 2018). Namun, produksi kedelai selalu mendapatkan tantangan, baik faktor genetik, teknologi budidaya maupun faktor abiotik lainnya.

Kebutuhan kedelai saat ini masih banyak dipenuhi dari impor, karena produksi domestik belum mencukupi. Strategi umum untuk meningkatkan produksi kedelai dapat didekati melalui lima sumber pertumbuhan, yaitu menambah luas panen, meningkatkan produktivitas, meningkatkan stabilitas, mengurangi kehilangan hasil dan perbaikan tehnik budidaya (Puslitbangtan, 1991). Kelima kinerja tersebut harus sinergis satu dengan yang lain menjadi satu kesatuan untuk mencapai satu sasaran yaitu peningkatan produksi.

Penanaman kedelai varietas unggul nasional seperti Varietas Anjasmoro, Kaba dan Bubarang sebaiknya dilakukan penanaman pada jarak tanam $40 \mathrm{~cm}$ x 20 $\mathrm{cm}, 40 \mathrm{~cm} \times 15 \mathrm{~cm}$ dan $30 \mathrm{~cm} \times 30 \mathrm{~cm}$ dengan dua biji per lubang tanam. Semakin subur lahan, sebaiknya jarak tanam semakin lebar (Chairunas, et al., 2009). Namun secara local jarak tanam belum tentu memberikan hasil dan pertumbuhan yang maksimal.

Pemberian zat pengatur tumbuh pada tanaman kedelai bertujuan untuk membuat tanaman menjadi lebih produktif. Giberelin $\left(\mathrm{GA}_{3}\right)$ dapat meningkatkan persentase bunga jadi polong. Hal ini terjadi karena pemberian $\mathrm{GA}_{3}$ pada tanaman akan meningkatkan kandungan auksin dan dapat mengurangi keguguran bunga sehingga persen bunga jadi polong meningkat. Peningkatan jumlah polong juga didukung oleh faktor lingkungan yang sesuai dan proses fotosintesis sehingga jumlah asimilat yang dihasilkan meningkat.

Penelitian ini dilakukan untuk mengetahui tentang peningkatan pertumbuhan dan produksi tanaman kedelai (Glycine $\max$ L. Merril) pada berbagai jarak tanam dan konsentrasi giberelin.

\section{II.METODELOGI PENELITIAN}

\section{Tempat, Alat dan Bahan Penelitian}

Penelitian ini dilaksanakan di Desa Cot Tufah Kecamatan Gandapura Kabupaten Bireuen dengan ketinggian tempat \pm 5 meter di atas permukaan laut (dpl).

Adapun bahan-bahan yang digunakan dalam penelitian ini adalah benih kedelai varietas Anjasmoro, giberelin $\left(\mathrm{GA}_{3}\right)$, pupuk urea, SP-36, $\mathrm{KCl}$, pupuk kandang sapi, pestisida Decis ${ }^{\circledR}$ dan $\operatorname{Temix}{ }^{\circledR}$. Sedangkan alat-alat yang digunakan dalam penelitian ini adalah cangkul, tugal, plank nama, gembor, hand sprayer, meteran, timbangan analitik, pipet tetes, gelas kimia serta alat pendukung lainnya.

\section{Metode Penelitian}

Penelitian ini menggunakan Rancangan Acak Kelompok (RAK) Pola Faktorial dengan 2 faktor, diantaranya sebagai berikut: (1) factor jarak tanam (J), terdiri dari 3 taraf yaitu $J_{1}(40 \mathrm{~cm} \times 20 \mathrm{~cm}), J_{2}(40$ $\mathrm{cm} \times 15 \mathrm{~cm})$ dan $\mathrm{J}_{3}:(30 \mathrm{~cm} \times 30 \mathrm{~cm}) ;(2)$ factor konsentrasi $\mathrm{GA}_{3}(\mathrm{G})$, terdiri dari 4 
taraf yaitu $\mathrm{G}_{0}\left(0 \mathrm{ppm}\right.$ (kontrol)), $\mathrm{G}_{1}(75$ ppm), $G_{2}\left(95\right.$ ppm) dan $G_{3}(115$ ppm). Dengan demikian terdapat 12 kombinasi perlakuan. Masing-masing kominasi perlakuan diulang 3 kali, sehingga terdapat 36 unit percobaan.

Data yang diperoleh dianalisis dengan Analisis Ragam atau Analysis of Variance (Anova). Apabila dari hasil uji Anova menunjukkan perlakuan berpengaruh nyata, maka dilakukan uji lanjutan dengan Uji DMRT (Duncan's Multiple Range Test) pada taraf $5 \%$.

\section{Pelaksanaan Penelitian}

Persiapan lahan dan aplikasi pupuk kandang. Lahan dibersihkan dari gulma dan sisa tanaman lainnya. Tanah diolah sampai gembur dengan menggunakan cangkul. Pembuatan bedengan/plot juga dilakukan dengan menggunakan cangkul. Ukuran plot 2 x 1 m sebanyak 36 buah dan dibuatkan saluran drainase dengan luas 50$60 \mathrm{~cm}$ dan tinggi $20 \mathrm{~cm}$. Selanjutnya diberikan pupuk kandang sapi sebagai pupuk dasar sebanyak 10 ton/ha atau 2 $\mathrm{kg} /$ plot.

Persiapan benih. Benih kedelai yang digunakan dalam penelitian ini yaitu benih kedelai Varietas Anjasmoro yang diperoleh dari Badan Penyuluhan Pertanian Kecamatan Peudada. Sebelum penanaman benih kedelai disortir kembali, beniih yang digunakan yang berwarna kekuningan, bentuknya padat dan mulus.

Penanaman. Penanaman dilakukan setelah dua minggu pengolahan tanah. Pembuatan lubang tanam dengan cara ditugal sedalam 2-3 cm, kemudian benih dimasukkan sebanyak 2-3 biji per lubang tanam. Pengaturan jarak tanam dalam penelitian ini yaitu: $40 \times 20 \mathrm{~cm}, 40 \times 15 \mathrm{~cm}$, dan 30 x $30 \mathrm{~cm}$.

\section{Pengaplikasian Giberelin $\left(\mathbf{G A}_{\mathbf{3}}\right)$.}

$\mathrm{GA}_{3}$ diaplikasi pada saat tanaman kedelai berumur 30 hari setelah tanam, yang mana tanaman masih dalam fase vegetatif. Pengaplikasian $\mathrm{GA}_{3}$ dilakukan pada sore hari dengan cara penyemprotan. Adapun konsentrasi yang diberikan yaitu 0 ppm, 75 ppm, 95 ppm, dan 115 ppm. Pembuatan larutan $\mathrm{GA}_{3}$ untuk konsentrasi 75 ppm adalah dengan melarutkan $75 \mathrm{mg} \mathrm{GA}_{3}$ dalam 1 liter air, dan selanjutnya diaplikasikan pada semua bagian tanaman. Cara yang sama juga dilakukan pada konsentrasi $\mathrm{GA}_{3}$ yang lain, yang digunakan pada penelitian.

Pemupukan. Pemupukan pertama dilakukan pada saat penanaman. Adapun pupuk yang yang diberikan adalah pupuk urea sebanyak $50 \mathrm{~kg} / \mathrm{ha}$ (10 g/plot), SP-36 sebanyak $50 \mathrm{~kg} / \mathrm{ha}(10 \mathrm{~g} / \mathrm{plot})$ dan pupuk $\mathrm{KCl}$ sebanyak $100 \mathrm{~kg} / \mathrm{ha}$ (20 g/plot). Cara pemberiannya dengan cara ditebar pada bedeng penanaman. Sedangkan pupuk susulan diberikan pada umur 30 hari setelah tanam. Pupuk yang diberikan yaitu urea sebanyak $50 \mathrm{~kg} / \mathrm{ha}(10 \mathrm{~g} / \mathrm{plot})$.

Pemeliharaan. Pemeliharaan tanaman dilakukan standar saja. Penyiraman dilakukan 2 kali sehari, pada pagi dan sore hari. Apabila terjadi hujan maka tidak dilakukan penyiraman. Pengendalian hama dilakukan pada saat tanaman berumur 30 hari setelah tanam akibat serangan ulat dengan pengaplikasian Decis ${ }^{\circledR}$, selanjutnya serangan hama tikus pada saat menjelang panen diatasi dengan aplikasi Temix ${ }^{\circledR}$.

Panen. Panen dilakukan pada saat tanaman berumur 100 hari setelah tanam atau pada saat tanaman sudah memperlihatkan kriteria panen yaitu daun sudah mengering dan polong sudah berwarna coklat tua.

Pengamatan. Adapun parameter pengamatan dalam penelitian ini adalah sebagai berikut:

1. Tinggi tanaman $(\mathrm{cm})$. Pengamatan tinggi tanaman dilakukan pada saat tanaman berumur $15,30,45$, dan 60 hari setelah tanam.

2. Jumlah cabang produktif. Pengamatan jumlah cabang dihitung pada saat akhir masa vegetatif aktif tanaman sampel yaitu pada hari ke 60 hari setelah tanam. 
3. Jumlah polong. Pengamatan jumlah polong dilakukan pada saat tanaman telah dipanen dengan cara menghitung jumlah polong per tanaman sampel.

4. Jumlah polong berisi. Pengamatan jumlah polong berisi dilakukan pada saat tanaman telah dipanen dengan cara menghitung polong berisi pada setiap tanaman sampel.

5. Berat kering 100 biji per plot (g). Pengamatan berat kering 100 biji dilakukan pada saat tanaman telah dipanen dengan cara menimbang biji kering sejumlah 100 biji.

\section{III.HASIL DAN PEMBAHASAN}

\section{A. Pengaruh Beberapa Jarak Tanam Terhadap Tanaman Kedelai}

Berdasarkan hasil pengamatan dan analisis ragam diketahui bahwa faktor jarak tanam berpengaruh nyata terhadap jumlah cabang produktif dan berat kering 100 biji. Akan tetapi faktor jarak tanam berpengaruh tidak nyata terhadap tinggi tanaman, jumlah polong dan jumlah polong berisi.

\section{Tinggi Tanaman}

Hasil analisis ragam menunjukkan bahwa perlakuan jarak tanam berpengaruh tidak nyata terhadap tinggi tanaman pada umur 15, 30, 45 dan 60 hari setelah tanam. Nilai rata-rata tinggi tanaman kedelai pada berbagai jarak tanam dan hari pengamatan dapat dilihat pada Tabel 1.

Tabel 1. Rata-Rata Tinggi Tanaman Kedelai Pada Beberapa Jarak Tanam Umur 15, 30, 45 dan 60 Hari Setelah Tanam (HST).

\begin{tabular}{ccccc}
\hline Jarak Tanam & \multicolumn{4}{c}{ Tinggi Tanaman Kedelai $(\mathrm{cm})$} \\
\cline { 2 - 5 }$(\mathrm{cm})$ & $15 \mathrm{HST}$ & $30 \mathrm{HST}$ & $45 \mathrm{HST}$ & $60 \mathrm{HST}$ \\
\hline $40 \times 20\left(\mathrm{~J}_{1}\right)$ & 12,97 & 36,62 & 94,59 & 100,20 \\
$40 \times 15\left(\mathrm{~J}_{2}\right)$ & 12,83 & 40,28 & 97,74 & 105,25 \\
$30 \times 30\left(\mathrm{~J}_{3}\right)$ & 13,48 & 39,69 & 99,54 & 105,75 \\
\hline
\end{tabular}

Keterangan: Perlakuan tidak berpengaruh nyata setelah diuji secara statistik.

Walaupun secara statistik tidak berpengaruh nyata, namun berdasarkan rata-rata pada Tabel 1 terlihat bahwa tanaman tertinggi dijumpai pada perlakuan jarak tanam $30 \mathrm{~cm} \times 30 \mathrm{~cm}\left(\mathrm{~J}_{3}\right)$ yaitu masing-masing $13,48 \mathrm{~cm}, 40,28 \mathrm{~cm}, 99,54$ $\mathrm{cm}$ dan $105,75 \mathrm{~cm}$ sedangkan tanaman terendah dijumpai pada perlakuan jarak tanam $40 \mathrm{~cm} \mathrm{x} 20 \mathrm{~cm}$ yaitu $12,79 \mathrm{~cm}$, $36,62 \mathrm{~cm}, 94,59 \mathrm{~cm}$ dan $100,20 \mathrm{~cm}$.

Pengamatan terhadap tinggi tanaman pada umur 15, 30, 45 dan 60 hari setelah tanam (masa vegetatif), faktor jarak tanam tidak memberikan pengaruh yang nyata. Hal ini dapat terjadi karena perlakuan yang digunakan tidak berbeda jauh tingkat kerapatannya. Tanaman mendapatkan unsur hara air dan air dalam jumlah yang cukup sehingga tidak terjadinya persaingan. Seperti disebutkan Sitompul dan Guritno (1995) dalam Musliadi (2012), bahwa tanaman tidak mengalami persaingan selama ketersediaan air, unsur hara dan cahaya, pada kondisi yang cukup untuk kebutuhan tanaman.

Beberapa penelitian menunjukkan bahwa jarak tanam terlalu rapat akan menyebabkan tinggi tanaman semakin tinggi dan secara nyata berpengaruh pada jumlah cabang dan luas daun. Hal tersebut mencerminkan bahwa pada jarak tanam rapat terjadi kompetisi dalam penggunaan cahaya yang mempengaruhi pula pengambilan unsur hara, air dan udara. Kompetisi cahaya terjadi apabila suatu tanaman menaungi tanaman lain atau apabila suatu daun memberi naungan pada daun lain. Tanaman yang saling menaungi akan berpengaruh pada proses fotosintesis. Dengan demikian tajuk-tajuk tumbuh kecil dan kapasitas pengambilan unsur hara serta air menjadi berkurang (Khavid, 2011). 


\section{Jumlah Cabang Produktif}

Hasil analisis ragam menunjukkan bahwa perlakuan jarak tanam berpengaruh nyata terhadap jumlah cabang produktif tanaman kedelai. Nilai rata-rata jumlah cabang produktif kedelai pada berbagai jarak tanam dapat dilihat pada Tabel 2.

Tabel 2. Rata-Rata Jumlah Cabang Produktif, Jumlah Polong dan Jumlah Polong Berisi pada Beberapa Jarak Tanam.

\begin{tabular}{cccc}
\hline Jarak Tanam $(\mathrm{cm})$ & $\begin{array}{c}\text { Jumlah Cabang } \\
\text { Produktif }\end{array}$ & Jumlah Polong & $\begin{array}{c}\text { Jumlah Polong } \\
\text { Berisi }\end{array}$ \\
\hline $40 \times 20\left(\mathrm{~J}_{1}\right)$ & $5,41 \mathrm{~b}$ & $105,52 \mathrm{a}$ & $91,83 \mathrm{a}$ \\
$40 \times 15\left(\mathrm{~J}_{2}\right)$ & $4,77 \mathrm{a}$ & $105,42 \mathrm{a}$ & $85,67 \mathrm{a}$ \\
$30 \times 30\left(\mathrm{~J}_{2}\right)$ & $5,27 \mathrm{~b}$ & $109,05 \mathrm{a}$ & $95,50 \mathrm{a}$ \\
\hline
\end{tabular}

Keterangan: Angka-angka yang diikuti oleh huruf yang sama pada kolom yang sama berbeda tidak nyata menurut Uji Duncan pada taraf 5\%.

Tabel 2 memperlihatkan bahwa nilai tertinggi dari jumlah cabang produktif dijumpai pada perlakuan jarak tanam 40 $\mathrm{cm}$ x $20 \mathrm{~cm}\left(\mathrm{~J}_{1}\right)$ yaitu 5,41 cabang, namun berbeda tidak nyata dengan jumlah jarak tanam 30 × $30 \mathrm{~cm}$. Cabang yang paling sedikit dijumpai pada perlakuan jarak tanam $40 \mathrm{~cm} \times 15 \mathrm{~cm}\left(\mathrm{~J}_{2}\right)$ yaitu 4,77 cabang.

Jarak tanam sangat mempengaruhi jumlah cabang suatu tanaman. Semakin lebar jarak tanaman yang digunakan maka semakin besar kesempatan tanaman untuk dapat membentuk cabang-cabang baru. Marjilianti (2008), menyatakan hal ini disebabkan karena pada jarak tanam renggang tersedia untuk perkembangan jumlah cabang dan persaingan antara tanaman rendah sehingga memungkinkan tumbuh tanpa hambatan. Tidak hanya jarak tanam, jumlah cabang juga dipengaruhi oleh kondisi lahan dan iklim di lapangan. Balitbangtan (2009), menyatakan bahwa tanaman kedelai varietas Anjasmoro yang memiliki tinggi tanaman $64-68 \mathrm{~cm}$ serta jumlah cabang yang berkisar antara 2,9-5,6 pada setiap tanaman.

\section{Jumlah Polong}

Hasil analisis ragam menunjukkan bahwa perlakuan jarak tanam tidak berpengaruh nyata terhadap jumlah polong tanaman kedelai. Nilai rata-rata jumlah polong kedelai pada berbagai jarak tanam dapat dilihat pada Tabel 2 .
Walaupun secara statistik tidak berpengaruh nyata, namun berdasarkan rata-rata pada Tabel 2 diperoleh bahwa secara statistik perlakuan jarak tanam berpengaruh tidak nyata terhadap terhadap jumlah polong berisi, namun secara angka ternyata jarak tanam $30 \mathrm{~cm}$ x $30 \mathrm{~cm}$ mampu memberikan jumlah polong tertinggi dibandingkan dengan jarak tanam $40 \mathrm{~cm} \times 20 \mathrm{~cm}$ dan $40 \mathrm{~cm} \times 15 \mathrm{~cm}$.

Untuk mendapatkan produksi yang optimum tanaman kedelai memerlukan perlakuan khusus di lapangan. Penentuan jarak tanam merupakan salah satu pilihan yang dianggap dapat meningkatkan hasil kedelai. Penggunaan jarak tanam yang rapat mampu meningkatkan populasi tanaman akan tetapi tanaman akan menjadi lunak dan mudah rebah. Penggunaan jarak tanam yang terlalu lebar juga dapat menurunkan produksi. Menurut Suprapto (1988) dalam Supriono (2000), jarak tanam yang terlalu rapat mempunyai beberapa kerugian yakni polong per tanaman menjadi sangat berkurang sehingga hasil per hektarnya menjadi rendah, ruas batang tumbuh lebih panjang sehingga tanaman kurang kokoh dan mudah roboh, benih yang dibutuhkan lebih banyak dan penyiangan sukar dilakukan.

\section{Jumlah Polong Berisi}

Hasil analisis ragam menunjukkan bahwa perlakuan jarak tanam tidak berpengaruh nyata terhadap jumlah polong berisi tanaman kedelai. Nilai rata-rata jumlah polong berisi kedelai pada 
berbagai jarak tanam dan jadwal/hari pengamatan dapat dilihat pada Tabel 2 .

Walaupun secara statistik tidak berpengaruh nyata, namun berdasarkan rata-rata pada Tabel 3 terlihat bahwa jumlah polong berisi terbanyak dijumpai pada perlakuan jarak tanam $30 \mathrm{~cm}$ x $30 \mathrm{~cm}$ $\left(\mathrm{J}_{3}\right)$ yaitu 95,50 polong sedangkan jumlah polong berisi yang paling sedikit dijumpai pada perlakuan jarak tanam $40 \mathrm{~cm}$ x $15 \mathrm{~cm}$ $\left(\mathrm{J}_{2}\right)$ yaitu 85,67 polong.

Jarak tanam sangat berpengaruh terhadap fotosintesis. Penggunaan jarak tanam yang sesuai akan meningkatkan proses fotosintesis dan fase generatif. Fotosintat yang dihasilkan akan dipergunakan untuk pembentukan organorgan generatif misalnya pengisian polong.
Hal ini didukung pula oleh pendapat Gardner (1991), fotosintesis selama periode pengisian biji biasanya menjadi sumber yang terpenting untuk berat hasil panen biji. Hal ini disebabkan karena sebelum pengisian biji, kebanyakan hasil asimilasi digunakan untuk produksi vegetatif dan produksi bunga, sedangkan selama pengisian biji kebanyakan hasil asimilasi digunakan untuk proses tersebut.

\section{Berat Kering 100 Biji}

Hasil analisis ragam menunjukkan bahwa perlakuan jarak tanam berpengaruh nyata terhadap berat kering 100 biji tanaman kedelai. Nilai rata-rata berat kering biji perplot kedelai pada berbagai jarak tanam dilihat pada Tabel 3.

Tabel 3. Rata-Rata Berat Kering 100 Biji Kedelai pada Beberapa Jarak Tanam.

\begin{tabular}{cc}
\hline Jarak Tanam $(\mathrm{cm})$ & Berat Kering 100 biji \\
\hline $40 \times 20\left(\mathrm{~J}_{1}\right)$ & $15,68 \mathrm{a}$ \\
$40 \times 15\left(\mathrm{~J}_{2}\right)$ & $16,44 \mathrm{~b}$ \\
$30 \times 30\left(\mathrm{~J}_{3}\right)$ & $15,22 \mathrm{a}$
\end{tabular}

Keterangan: Angka-angka yang diikuti oleh huruf yang tidak sama pada baris dan kolom yang sama berpengaruh nyata menurut uji Duncan pada taraf 5\%.

Dari Tabel 9 diperoleh berat 100 biji per plot tertinggi dijumpai pada perlakuan jarak tanam $40 \mathrm{~cm} \times 15 \mathrm{~cm}\left(\mathrm{~J}_{2}\right)$ yaitu 16,44 biji sedangkan berat 100 biji terendah dijumpai pada perlakuan jarak tanam $40 \mathrm{~cm} \times 20 \mathrm{~cm}\left(\mathrm{~J}_{1}\right)$ yaitu 15,22 biji. Hasil pengamatan menunjukkan bahwa perlakuan jarak tanam $40 \mathrm{~cm} \times 15 \mathrm{~cm}\left(\mathrm{~J}_{2}\right)$ berbeda tidak nyata dengan perlakuan jarak tanam $40 \mathrm{~cm} \times 20 \mathrm{~cm}\left(\mathrm{~J}_{1}\right)$, dan perlakuan jarak tanam $30 \mathrm{~cm} \mathrm{x30} \mathrm{cm}\left(\mathrm{J}_{3}\right)$.

Pada jarak tersebut kesempatan tumbuh gulma semakin sempit sehingga kompetisi unsur hara antara tanaman dan gulma semakin kecil terjadi. Ketersediaan hara pada tanah dapat sepenuhnya dimanfaatkan oleh tanaman untuk pembentukan biji. Jarak tanam mempengaruhi populasi tanaman, kompetisi tanaman dan keefisienan penggunaan cahaya, mempengaruhi kompetisi dalam menggunakan air dan hara, dengan demikian akan mempengaruhi hasil. Pada umumnya produksi per satuan luas tinggi tercapai dengan populasi yang tinggi pula, karena tercapainya penggunaan cahaya secara maksimal di awal pertumbuhan akan tetapi akhirnya, penampilan masing-masing tanaman secara individu akan menurun karena persaingan cahaya dan faktor tumbuh lainnya (Harjadi, 2006).

\section{B. Pengaruh Beberapa Konsentrasi Giberelin Terhadap Tanaman Kedelai}

Berdasarkan hasil penelitian dan analisis ragam diketahui bahwa konsentrasi giberelin berpengaruh nyata terhadap tinggi tanaman 45 dan 60 hari setelah tanam dan berat kering 100 biji. Akan tetapi tidak berpengaruh nyata terhadap jumlah daun, jumlah cabang, jumlah polong, jumlah polong berisi, serta persentase polong berisi. 


\section{Tinggi Tanaman}

Hasil analisis ragam menunjukkan bahwa konsentrasi giberelin tidak berpengaruh nyata terhadap tinggi tanaman pada 15 dan 30 hari setelah tanam, namum berpengaruh sangat nyata pada 45 dan 60 hari setelah tanam. Nilai rata-rata tinggi tanaman pada umur 15, 30, 45 dan 60 hari setelah tanam dapat dilihat pada Tabel 4.

Tabel 4. Rata-Rata Tinggi Tanaman Kedelai Pada Beberapa Konsentrasi Giberelin pada Umur 15, 30, 45 dan 60 Hari Setelah Tanam.

\begin{tabular}{ccccc}
\hline Konsentrasi & \multicolumn{4}{c}{ Tinggi tanaman kedelai $(\mathrm{cm})$} \\
\cline { 2 - 5 } & $15 \mathrm{HST}$ & $30 \mathrm{HST}$ & $45 \mathrm{HST}$ & $60 \mathrm{HST}$ \\
\hline $0 \mathrm{ppm} /$ kontrol $\left(\mathrm{G}_{0}\right)$ & $8.33 \mathrm{a}$ & $49.07 \mathrm{a}$ & $78.21 \mathrm{a}$ & $78.92 \mathrm{a}$ \\
$75 \mathrm{ppm}\left(\mathrm{G}_{1}\right)$ & $8.37 \mathrm{a}$ & $48.48 \mathrm{a}$ & $108.39 \mathrm{c}$ & $109.29 \mathrm{~b}$ \\
$95 \mathrm{ppm}\left(\mathrm{G}_{2}\right)$ & $8.33 \mathrm{a}$ & $50.74 \mathrm{a}$ & $106.40 \mathrm{ab}$ & $113.49 \mathrm{~b}$ \\
$115 \mathrm{ppm}\left(\mathrm{G}_{3}\right)$ & $8.26 \mathrm{a}$ & $40.11 \mathrm{a}$ & $96.15 \mathrm{~b}$ & $107.90 \mathrm{~b}$ \\
\hline
\end{tabular}

Keterangan: Angka-angka yang diikuti oleh huruf yang sama pada kolom yang sama berbeda tidak nyata menurut uji Duncan pada taraf 5\%.

Tabel 4 memperlihatkan bahwa tinggi tanaman kedelai tertinggi pada 15 HST dijumpai pada perlakuan konsentrasi giberelin $75 \mathrm{ppm}\left(\mathrm{G}_{1}\right)$ namun berbeda tidak nyata dengan perlakuan lainnya (kontrol, 95 dan 115 ppm). Pada pengamatan 30 HST tanaman tertinggi dijumpai pada perlakuan kontrol $\left(\mathrm{G}_{0}\right)$ namun berbeda tidak nyata dengan perlakuan lainnya $(75,95$ dan $115 \mathrm{ppm})$. Pada pengamatan 45 HST tanaman tertinggi dijumpai pada perlakuan $75 \mathrm{ppm}$ $\left(G_{1}\right)$, perlakuan tersebut berbeda nyata dengan perlakuan lainnya (kontrol, 95 dan 115 ppm). Sedangkan pada umur 60 hari setelah tanam, tinggi tanaman tertinggi dijumpai pada perlakuan 95 ppm, namun berbeda tidak nyata dengan perlakuan 75 ppm dan 115 ppm, akan tetapi berbeda nyata dengan perlakuan kontrol. Pada pengamatan 15 dan 30 hari setelah tanam tinggi tanaman antar perlakuan belum menunjukkan perbedaan yang signifikan karena giberelin diberikan pada hari ke 30 setelah tanam.
Peningkatan tinggi tanaman
diakibatkan adanya pengaplikasian giberelin pada 30 hari setelah tanam. Hal ini dapat terjadi karena giberelin bekerja pada gen dengan menyebabkan aktivasi gen-gen tertentu. Gen-gen yang diaktifkan akan membentuk enzim-enzim baru yang menyebabkan terjadinya perubahan morphogenetik (penampilan/kenampakan tanaman) salah satunya penambahan tinggi batang. Taiz dan Zeiger (1995) menyatakan bahwa giberelin dapat meningkat perpanjangan batang dan pembelahan sel, yang dibuktikan dengan bertambahnya panjang sel dan jumlah sel sebagai respon dari aplikasi giberelin.

\section{Jumlah Cabang Produktif}

Hasil pada analisis ragam menunjukkan bahwa konsentrasi giberelin tidak berpengaruh nyata terhadap jumlah cabang produktif tanaman kedelai. Nilai rata-rata jumlah cabang produktif tanaman pada beberapa konsentrasi giberelin dapat dilihat pada Tabel 5.

Table 5. Rata-Rata Jumlah Cabang Produktif Tanaman Kedelai Pada Beberapa Konsentrasi Giberelin.

\begin{tabular}{cccc}
\hline Konsentrasi & $\begin{array}{c}\text { Jumlah cabang } \\
\text { produktif }\end{array}$ & Jumlah Polong & Jumlah Polong Berisi \\
\hline 0 ppm/kontrol (G0) & 5,07 & 115.92 & 93,03 \\
75 ppm (G1) & 5,29 & 109.96 & 96,04 \\
95 ppm (G2) & 5,29 & 102.70 & 85,18 \\
115 ppm (G3) & 496 & 97.59 & 90,14 \\
\hline
\end{tabular}

Keterangan: Perlakuan tidak berpengaruh nyata setelah diuji secara statistik. 
Meskipun secara statistik tidak berpengaruh nyata, namun berdasarkan rata-rata pada Tabel 12 diperoleh jumlah cabang produktif dijumpai pada perlakuan konsentrasi giberelin 75 ppm $\left(\mathrm{G}_{1}\right)$ dan konsentrasi giberelin $95 \mathrm{ppm}\left(\mathrm{G}_{2}\right)$ yaitu 5.29 cabang sedangkan jumlah cabang tanaman kedelai terendah dijumpai pada perlakuan 115 ppm $\left(\mathrm{G}_{3}\right)$ yaitu 4.96 cabang.

Pengamatan terhadap jumlah cabang menunjukkan tidak adanya pengaruh yang nyata, hal ini dapat diduga akibat pemberian dosis yang tidak sesuai, bisa juga dikaitkan dengan sifat genetis tanaman itu sendiri.

Giberelin sebagai hormon tumbuh pada tanaman, sangat berpengaruh terhadap sifat genetik, pembungaan, penyinaran, partehenocarpy, mobilisasi karbohidrat selama perkecambahan dan aspek fisiologis lainnya. Giberelin mempunyai peranan dalam mendukung perpanjangan sel, aktivitas kambium dan mendukung pertukaran RNA baru serta sintesis protein (Abidin, 1993).

\section{Jumlah Polong}

Hasil analisis ragam menunjukkan bahwa konsentrasi giberelin berpengaruh tidak nyata terhadap jumlah polong tanaman kedelai.Nilai rata-rata jumlah polong tanaman kedelai pada beberapa konsentrasi giberelin dapat dilihat pada Tabel 5.

Secara statistik tidak berpengaruh nyata, namun berdasarkan rata-rata pada Tabel 5 diperoleh jumlah polong tertinggi dijumpai pada perlakuan kontrol $\left(\mathrm{G}_{0}\right)$ yaitu 115,92 polong sedangkan jumlah polong tanaman kedelai terendah dijumpai pada perlakuan 115 ppm $\left(\mathrm{G}_{3}\right)$ yaitu 97,59 polong. Konsentrasi giberelin yang diberikan terhadap tanaman kedelai tidak sesuai. Kondisi iklim saat aplikasi juga sangat berpengaruh terhadap kebutuhan suatu tanaman. Cristiningsih (2008), menyatakan giberelin tidak memberi pengaruh terhadap pertumbuhan dan persentase buah pada tanaman buncis. Giberelin hanya dapat disintetis pada dosis yang sesuai.

\section{Jumlah Polong Berisi}

Hasil analisis ragam menunjukkan bahwa konsentrasi giberelin tidak berpengaruh nyata terhadap jumlah polong berisi tanaman kedelai. Nilai rata-rata jumlah polong berisi kedelai tanaman pada beberapa konsentrasi giberelin dapat dilihat pada Tabel 5.

Walaupun secara statistik tidak berpengaruh nyata, namun berdasarkan rata-rata pada Tabel 5 jumlah polong berisi tertinggi dijumpai pada perlakuan $75 \mathrm{ppm}$ $\left(\mathrm{G}_{1}\right)$ yaitu 96,04 polong sedangkan jumlah polong berisi tanaman kedelai terendah dijumpai pada perlakuan $95 \mathrm{ppm}\left(\mathrm{G}_{2}\right)$ yaitu 85.18 polong. Konsentrasi zat pengatur tumbuh yang diberikan pada tanaman sangat berpengaruh terhadap pertumbuhan dan perkembangan tanaman. Sesuai dengan sifat zat tersebut pada dosis tinggi dapat menyebabkan terhentinya proses pertumbuhan dan perembangan tanaman, sebaliknya pada dosis yang sangat rendah pemberian zat pengatur tumbuh tidak efektif. Mursito (2003) dalam Silitonga (2010) mengatakan bahwa ukuran biji maksimun pada tiap tanaman ditentukan secara genetik, namun ukuran biji yang terbentuk juga ditentukan oleh lingkungan semasa pengisian biji.

\section{Berat Kering 100 Biji}

Hasil analisis ragam menunjukkan bahwa konsentrasi giberelin berpengaruh nyata terhadap berat kering 100 biji tanaman kedelai. Nilai rata-rata berat kering 100 biji kedelai tanaman pada beberapa konsentrasi giberelin dapat dilihat pada Tabel 6. 
Tabel 6. Rata-Rata Berat Kering 100 Biji Tanaman Kedelai Pada Beberapa Konsentrasi Giberelin.

\begin{tabular}{cc}
\hline Konsentrasi & Berat $100 \mathrm{Biji}$ \\
\hline 0 ppm/kontrol (G0) & $16.55 \mathrm{~b}$ \\
$75 \mathrm{ppm}(\mathrm{G} 1)$ & $15.77 \mathrm{ab}$ \\
$95 \mathrm{ppm}(\mathrm{G} 2)$ & $15.15 \mathrm{a}$ \\
$115 \mathrm{ppm}(\mathrm{G} 3)$ & $15.64 \mathrm{a}$ \\
\hline
\end{tabular}

Keterangan: Angka-angka yang diikuti oleh huruf yang sama pada kolom yang sama berbeda tidak nyata menurut uji Duncan pada taraf 5\%.

Dari Tabel 6 terlihat bahwa berat kering 100 biji tertinggi dijumpai pada perlakuan kontrol $\left(\mathrm{G}_{0}\right)$ yaitu $16.55 \mathrm{~g}$ sedangkan berat 100 biji terendah dijumpai pada perlakuan 95 ppm $\left(\mathrm{G}_{2}\right)$ yaitu $15.15 \mathrm{~g}$. Perlakuan $\mathrm{G}_{2}$ berbeda tidak nyata terhadap perlakuan $G_{3}$ dan perlakuan perlakuan $G_{1}$ namun berbeda nyata terhadap perlakuan $\mathrm{G}_{0}$.

Tanaman kedelai varietas anjasmoro mampu menghasilkan berat 100 biji berkisar antara 14,8 sampai 15,3 g (Badan Penelitian dan Pengembangan Pertanian, 2009).

Tetapi pada Tabel 17 terlihat bahwa ratarata berat kering 100 biji melebihi potensi hasil dan berat tertinggi pada perlakuan kontrol. Hal ini mungkin oleh karena cukupnya kebutuhan hara dan makanan untuk tanaman dalam menghasilkan biji.

Tanah sebagai media tumbuh tanaman mempunyai daya dukung terbatas sebagai sumber unsur hara maupun sebagai penampung tanbahan input hara berupa pupuk. Selain itu, setiap lahan/ tanah memunyai tingkat keragaman tanggap yang cukup besar, tergantung individu tanaman atau varietas yang digunakan. Kondisi ini menyebabkan keragaman produktivitas untuk setiap individu tanaman. Oleh karena itu, kombinasi pengelolaan sumber daya tanah dan aplikasi pupuk harus dilakukan secara efesien dan efektif agar manfaatnya bisa dinikmati secara bekelanjutan tanpa menimbulkan efek samping yang merusak lingkungan (Adisarwanto, 2002).

\section{IV.SIMPULAN DAN SARAN}

\section{Simpulan}

1. Perlakuan jarak tanam berpengaruh nyata terhadap jumlah cabang produktif dan berat kering 100 biji. Perlakuan terbaik dijumpai pada jarak tanam 30 $\mathrm{cm} \times 30 \mathrm{~cm}\left(\mathrm{~J}_{3}\right)$.

2. Konsentrasi Giberelin berpengaruh sangat nyata terhadap tinggi tanaman pada pengamatan 45 dan 60 hari setelah tanam dan berat kering 100 biji. Perlakuan terbaik dijumpai pada konsentrasi 95 ppm .

\section{Saran}

1. Untuk memperoleh hasil yang baik pada penanaman kedelai dapat digunakan jarak tanam $30 \mathrm{~cm} \times 30 \mathrm{~cm}$.

2. Keadaan lingkungan (cuaca) pada saat aplikasi giberelin harus diperhatikan agar dapat memberi pengaruh yang nyata terhadap tanaman kedelai.

\section{DAFTAR PUSTAKA}

Abidin, Z. 1993. Dasar-dasar Pengetahuan Tentang Giberelin. Angkasa. Bandung.

Adisarwanto, T. 2008. Budi Daya Kedelai Tropika. Penebar Swadaya. Jakarta.

Badan Penelitian dan Pengembangan

Pertanian (Balitbangtan). 2009.

Kedelai dan Cara Bercocok

Tanamnya. Sekretariat Badan

Pengendalian Bimas. Bogor.

Badan Pusat Statistik (BPS). 2018. Berita Resmi Statistik. Available at. 
http//www.bps.go.id/brs-file/aram [5 Desember 2018].

Chairunnas, T. Iskandar dan B. Abubakar. 2009. Budi Daya Kedelai di Lahan Sawah Bekas Tsunami. Balai Pengkajian Teknologi Pertanian NAD. Banda Aceh.

Cristiningsih, R. 2008. Pengaruh triakontanol dan Giberelin Terhadap Pertumbuhan dan Persentase Buah Jadi Tanaman Buncis. Agros. 10 (2): 35-42. Available at. http://isjd.pdii.lipi.go.id/admin/jurnal /101083540_1411-0172.pdf. [5 September 2018].

Fauzi, A. R., dan Puspitawati, M. D. 2018. Cultivation of soybean of Burangrang variety in dry land. Jurnal Bioindustri. Vol. 1(1): 1-9.

Fried, H.G., Narayanan, S., Fallen, B. (2018). Characterization of a soybean (Glycine max L. Merr.) germplasm collection for root traits. PLoS ONE 13(7): e0200463. https://doi.org/10.1371/journal.pone. 0200463. [30 Januari 2020].

Gardner, F.P., R. B. Pearce, dan R. L. Mitchell. 1991. Fisiologi Tumbuhan. Universitas Indonesia Press. Jakarta.

Harjadi, S.S,. 2006. Pengantar Agronomi. Gramedia. Jakarta.

Khavid. 2011. Pertumbuhan dan Hasil Beberapa Genotip Kedelai Dengan Jarak Tanam Yang Berbeda Di Lahan Pasir Pantai. Available at:http://rindangcodot.blogspot.com/ 2011/02/proposal-penelitian-pakkhavid-1.html. [23 Desember 2018].

Marjilianti, W. 2008. Pengaruh Jarak Tanam dan Pemberian Dsis Pupuk
Kandang Terhadap pertumbuhan dan Hasil Tanaman Sawi Hijau (Brassica campestris $\mathrm{x}$ Brassica napus). Primordia 4 (1):1-14. Available at. http:isid.pdii.lipi.go.id/admin/jurnal/ 40108114_0216_7093.

Musliadi. 2012. Pertumbuhan dan Hasil Tanaman Selada Akibat Jarak Tanam dan Sistem Olah Tanah Yang Berbeda. Skripsi (tidak dipublikasikan) Program Studi Agronomi Fakultas Pertanian Universitas Malikussaleh. Aceh Utara.

Puslitbangtan. 1991. Sumber Pertumbuhan Produksi Padi dan Kedelai Potensi dan Peluang. Pusat Penelitian dan Pengembangan Tanaman Pangan. Bogor.

Silitonga, R. 2010. Pengaruh Pemberian $\mathrm{GA}_{3}$ Terhadap Beberapa Varietas Kedelai (Glycine max L. Merrill) Selama Fase Generatif. Program Studi Pemuliaan Tanaman. Departemen Budidaya Pertanian. Fakultas Pertanian Universitas Sumatera Utara. Medan. Available at.

http://Repository.usu.ac.id/handle/12 3456789/16344. [23 Desember 2018].

Taiz, L dan E. Zeiger. 1995. plant Physiology. The Benjamin / Cummings Publishing Company, Inc. Redwood City, California. 